\title{
ANALISIS PENANGANAN KREDIT MACET
}

\author{
Luluk Ambarsita \\ Program Studi Manajemen FEB UMM \\ E-mail:lu2k_412sita@yahoo.com
}

\begin{abstract}
Non-performing loans are loans with certain risks caused by debtor's failure to perform his/her obligations. In banking activities, non-performing loan could be affected by internal as well as external factor. The risk of non-performing loan will be reduced considerably by the prudential principle and other credit analysis principles are fully followed by bank as the creditor. This describes how the bank especially PT BRI (Persero) Tbk. Branch at Lamongan, managed and approved the applications of loan submitted by its prospective debtors. The models and methods used by the bank to handle credit default were also explored in this study. To deal with non-performing loan, PT BRI (Persero) Tbk. Lamongan Branch used several methods, namely Credit restructuration, amicable settlement involving the direct selling of collateral as well as legal settlement involving KPKNL (The Office for State Assets and Auction Service) were utilized to handle credit default.
\end{abstract}

Keywords: Non-performing loan, credit default, credit settlement

\section{PENDAHULUAN}

Dalam kondisi perekonomian yang sedang mengalami kelesuan seperti saat ini yang disebabkan tidak berkembangnya sektor riil, maka sangat dibutuhkan adanya suntikan dana fresh money baik dari pihak pemerintah melalui Lembaga Keuangan Bank ataupun Lembaga Keuangan Bukan Bank. Bank merupakan salah satu penggerak perekonomian. Oleh karena itu perbankan mempunyai peranan yang sangat penting dalam menunjang pembangunan naasional dalam rangka memeratakan pembangunan dan stabilitas nasional. Sektor perbankan selain dimanfaatkan untuk mendapatkan suntikan dana untuk meningkatkan usaha, juga dimanfaatkan oleh masyarakat untuk memenuhi kebutuhan sekunder mereka.

Lady (2008), menyatakan pasar keuangan mikro Indonesia didominasi oleh dua jenis lembaga resmi yaitu: 4.000 lebih kantor Unit, yang merupakan kantor-kantor cabang pembantu Bank Rakyat Indonesia (BRI, yang sedang menjalani privatisasi), dan hampir 2.200 Bank Perkreditan Rakyat(BPR), yang mewakili bank-bank yang lain. BRI disebut menguasai sekitar $45 \%$ portofolio Keuangan Mikro, sedangkan BPR sekitar 30\%. Koperasi berperan besar dalam penyaluran kredit (sekitar 20\% dari pangsa pasar), namun kurang berperan dalam penggalangan tabungan: BRI Unit menghimpun sekitar 75\%, sedangkan BPR menghimpun 20\% dana.

Dalam kehidupan sehari-hari kredit bukan merupakan barang asing bagi masyarakat. Kredit tidak hanya dikenal oleh masyarakat kota saja tetapi masyarakat pedesaan pun sudah sangat populer. Setiap kredit yang diberikan oleh Lembaga Keuangan Bank ataupun Lembaga Keuangan Bukan Bank mengandung resiko, sehingga perlu diminimalisir dengan cara yang lebih selektif dalam pemberian kredit karena bank memberikan kepercayaan pada debitur untuk mengembalikan uang yang diterima dari nasabah yang menyimpan uangnya di bank. 
Menurut undang-undang nomor 10 tahun 1998, kredit adalah penyediaan uang atau tagihan yang dapat dipersamakan dengan itu, berdasarkan persetujuan atau kesepakatan pinjam-meminjam atara bank dan pihak lain, yang mewajibkan untuk melunasi hutangnya setelah jangka waktu tertentu dengan jumlah bunga, imbalan atau pembagian hasil keuntungan baik bersifat langsung maupun tidak langsung. Kredit yang dianalisa dengan prinsip kehati-hatian akan menempatkan kredit pada kualitas kredit yang performing loan sehingga dapat memberikan pendapatan yang besar bagi pihak bank. Pendapatan tersebut diperoleh dari besarnya selisih antara biaya dana dengan pendapatan bunga yang dibayar para pemohon kredit sehingga untuk mencapai keuntungan tersebut maka sejak awal permohonan kredit harus dilakukan analisis yang akurat.

Kegiatan perkreditan adalah risk asset bagi bank karena asset bank dikuasai oleh pihak luar bank, yaitu para debitor, akan tetapi kredit yang diberikan kepada para debitor selalu ada risiko berupa kredit tidak kembali tepat pada waktunya yang dinamakan kredit bermasalah. Banyak terjadi kredit yang diberikan menjadi bermasalah yang disebabkan berbagai alasan, misalnya usaha yang dibiayai dengan kredit mengalami kebangkrutan atau merosot omset penjualannya. Penyebab lainnya disebabkan oleh kesalahan analisis yang dilakukan oleh bank. Terhadap kredit bermasalah yang timbul tersebut diperlukan penanganan dengan cepat oleh pihak bank agar tidak berkelanjutan menjadi kredit macet (Non Perfoming Loan) dan jika presentasenya sudah melampaui batas yang telah ditetapkan oleh Bank Indonesia akan mempengaruhi kesehatan dari suatu bank.

Pembatasan masalah dalam penelitian ini adalah: ruang lingkup penelitian di titikberatkan pada pemberian kredit yang meliputi faktor-faktor yang mempengaruhi kredit bermasalah dan penyelesaian kredit bermasalah pada PT. Bank Rakyat Indonesia (Persero) Tbk. Cabang Lamongan. Tujuan Penelitian untuk mengetahui untuk mengetahui gambaran tentang prosedur pemberian kredit, penyebab terjadinya kredit bermasalah, dan penyelesaian kredit bermasalah pada PT. Bank Rakyat Indonesia (Persero) Tbk. Cabang Lamongan.

\section{TINJAUAN PUSTAKA}

Menurut hasil penelitian Ekani Siti Noorhayati (2010) dengan judul Prosedur Kredit Dan Upaya Mengatasi Kredit Bermasalah Pada PD. BPR BKK Jati Kudus. Penyebab kredit bermasalah tersebut bisa terjadi karena faktor internal diantaranya kebijakan perkreditan yang kurang menunjang, kelemahan sistem dan prosedur penilaian kredit, pemberian dan pengawasan kredit yang menyimpang, dan itikad yang kurang baik dari pemilik, pengurus, dan pegawai bank. Sedangkan faktor eksternal diantaranya adanya unsur sengaja dan tidak sengaja dari pihak nasabah. Solusi yang ditempuh bank dalam menangani kreditbermasalah antara lain dengan mendatangi debitur yang melakukan tunggakan, penyelesaian secara damai, pemberian keringanan bunga, penjualan agunan, penyelesaian melalui jalur hukum, penghapusan kredit, dan penghentian penagihan.

Taswan (2010) menguraikan bahwa kredit berasal dari kata credere atau creditum. Credere berasal dari bahasa Yunani yang berarti kepercayaan, sementara creditum yang berarti kepercayaan akan kebenaran. Arti kata tersebut mempunyai implikasi bahwa setiap kegiatan perkreditan harus dilandasi kepercayaan. Tanpa kepercayaan maka tidak akan terjadi pemberian kredit oleh bank maupun sebaliknya tidak ada calon nasabah menyepakati kredit, sebab pemberian kredit oleh bank mempunyai nilai ekonomi kepada nasabah perorangan atau badan usaha. Nilai ekonomi yang akan diperoleh nasabah debitur dan kreditur (bank) harus disepakati sejak awal (ada komitmen) tanpa merugikan salah satu pihak.

Menurut Undang-Undang Nomor 10 Tahun 1998 kredit adalah penyediaan uang atau tagihan yang dapat dipersamakan dengan itu, berdasarkan persetujuan atau kesepakatan pinjam meminjam antara bank dan pihak lain yang mewajibkan pihak peminjam untuk melunasi utangnya setelah jangka waktu dengan pemberian bunga. Dana yang dihimpun oleh bank disalurkan kembali ke masyarakat dalam bentuk kredit. Kredit merupakan penempatan dana yang paling menguntungkan, namun resiko yang dihadapi juga besar. Oleh karena itu bank (debitur) harus berhati-hati dalam penem- 
patan dana dalam bentuk kredit. Dalam pakteknya kreditur diharuskan menganalisis terlebih dahulu kredit yang akan diberikan kepada calon kreditur sehingga tidak membahayakan bank. Sehingga apabila terdapat data-data fiktif dengan mudah kreditur mengetahui. Walaupun kesalahan analisis ini bukan satu-satunya faktor penyebab kredit macet.

Menurut Kasmir (2011) unsur-unsur yang terkandung dalam pemberian suatu fasilitas kredit adalah sebagai berikut: 1) Kepercayaan, merupakan suatu keyakinan bagi si pemberi kredit bahwa kredit yang diberikan benar- benar diterima kembali di masa yang akan datang sesuai jangka waktu kredit, 2) Kesepakatan, dituangkan dalam suatu perjanjian di mana masing- masing pihak manandatangani hak dan kewajibannya masingmasing, 3) Jangka Waktu, setiap kredit yang diberikan memiliki jangka waktu tertentu, jangka waktu ini mencakup masa pengembalian kredityang telah disepakati, 4) Risiko, Akibat adanya tenggang waktu, akan memunkinkan suatu risiko tidak tertagihnya atau macet pemberian kredit. Semakin lama kredit yang diberikan semakin tinggi pula tingkat risikonya. Risiko yang terjadi dalam proses pemberian kredit ini akan menjadi tanggungan bank, 5) Balas Jasa, merupakan keuntungan atau pendapatan yang diterima oleh bank atas pemberian kredit. Balas jasa yang diterima oleh bank berupa bunga dan biaya administrasi kredit yang ditanggung oleh debitur.

Tujuan penyaluran kredit adalah: 1) Memperoleh pendapatan bank dari bunga kredit, 2) Memanfaatkan dan memproduktifkan danadana yang ada, 3) Melaksanakan kegiatan operasional bank, 4) Memenuhi permintaan kredit dari masyarakat, 5) Memperlancar proses pembayaran, 6) Menambah modal kerja perusahaan, 7) Meningkatkan pendanaan dan kesejahteraan masyarakat (Hasibuan, 2001). Untuk melindungi uang yang dikucurkan lewat kredit dari resiko kerugian. Resiko kredit macet kapan pun dapat terjadi tanpa bisa dihindari. Biasanya untuk mengurangi resiko tersebut bank meminta jaminan pada pihak debitur. Tujuan dari jaminan tersebut adalah untuk melindungi kredit dari resiko kerugian, baik yang disengaja maupun tidak disengaja.
Taswan (2010) menjelaskan bahwa kredit bermasalah sebenarnya bersifat kasuasitas, yang artinya masalah yang ada pada satu debitur akan berbeda dengan debitur lainnya. Kredit macet atau bermasalah yang terjadi secara tiba-tiba tanpa dimulai serangkaian tanda-tanda atau sinyal adalah sangat langka. Menurut Kasmir (2011) adapun yang lazim dilakukan bank adalah melalui: 1) Penjadwalan kembali pembayaran kredit (rescheduling), 2) Peninjauan kembali isi perjanjian kredit (reconditioning), 3) Retructuring, 4) Kombinasi merupakan kombinasi dari ketiga jenis yang diatas, 5) Penyitaan jaminan.

Prosedur pemberian kredit maksudnya adalah tahap-tahap yang harus dilalui sebelum suatu kredit diputuskan untuk dikucurkan. Tujuan ini untuk mempermudah bank dalam menilai kelayakan suatu permohonan kredit. Prosedur pemberian dan penilaian kredit oleh dunia perbankan secara umum antara bank yang satu dengan lain tidak jauh berbeda. Secara umum prosedur pemberian kredit oleh badan hukum sebagai berikut: 1) Pengajuan berkas-berkas, 2) Penyelidikan berkas pinjaman, 3) Wawancara I, bertujuan untuk menyakinkan bank apakah berkas-berkas tersebut sesuai dan lengkap seperti dengan yang bank inginkan, 4) On the spot merupakan kegiatan pemeriksaan kelapangan dengan meninjau berbagai objek yang akan dijadikan usaha atau jaminan, 5) Wawancara II merupakan perbaikan berkas, 6) Keputusan kredit kegiatan untuk menentukan apakah kredit akan diberikan atau ditolak, 7) Penandatanganan akad kredit/ perjanjian lainnya, 8) Realisasi kredit diberikan setelah penandatanganan akad kredit dengan membuka rekening giro atau tabungan di bank yang bersangkutan, 9) Penyaluran/penarikan dana dari rekening, 10) Berdasarkan prospek usaha kredit digolongkan menjadi 5 kelas yaitu: lancar, dalam perhatian khusus,kurang lancar, diragukan, dan macet.

\section{METODE PENELITIAN}

Penelitian ini berlokasi di PT. Bank Rakyat Indonesia (Persero) Tbk. Cabang Lamongan yang beralamat di Jalan Basuki Rahmad No. 86 
Lamongan. Jenis penelitian yang digunakan adalah diskriptif karena sifatnya hanya menggambarkan tetang prosedur pemberian kredit, faktor-faktor penyebab kredit bermasalah dan penyelesaian kredit bermasalah pada BRI cabang Lamongan. Sumber data digunakan dalam penelitian ini adalah data primer dan sekunder. Dalam penelitian ini data primer diperoleh dari Wawancara dilakukan dengan karyawan untuk mengetahui hal-hal yang berkaitan dengan penyelesaian kredi bermasalah pada PT. Bank Rakyat Indonesia (persero) Tbk, Cabang Lamongan. Data sekunder diperoleh dari pihak bank yang berupa dokumen tentang data kredit.

Teknik yang digunakan dalam mengumpulkan data dilakukan melalui: Dokumentasi, yaitu mempelajari serta menyalin dokumen yang berhubungan dengan data yang diperoleh dari PT. Bank Rakyat Indonesia (Persero) Tbk, Cabang Lamongan. Data tersebut berupa struktur organisasi, NPL, Jumlah nasabah yang yang mengalami kredit macet. Wawancara dilakukan dengan karyawan untuk mengetahui hal-hal yang berkaitan dengan penyelesaian kredit bermasalah pada PT. Bank Rakyat Indonesia (persero) Tbk. Cabang Lamongan. Definisi operasional variabel yang digunakan untuk mengetahui penanganan kredit bermasalah pada BRI Cabang Lamongan adalah Penjadwalan kembali pembayaran kredit/ rescheduling, Peninjauan kembali isi perjanjian kredit/ reconditioning, Retructuring, kombinasi, dan Penyitaan jaminan.

Teknik analisa data yang digunakan adalah metode deskriptif-kualitatif, langkah-langkah dalam analisis penyelesaian kredit macet: Mengumpulkan data-data yang terkait dengan prosedur dan pelaksanaan pemberian kredit sehingga dapat digambarkan bagaimana prosedur dan pelaksanaan pemberian kredit pada BRI cabang Lamongan. Penyebab terjadinya kredit mact pada BRI cabang Lamongan terdapat dua faktor yaitu faktor eksternal dan internal. Membandingkan antara pedoman dengan pelaksanaan penyelesaian kredit sudah sesuai dengan data yang ada.

Kriteria penilaian kredit antara lain: 1) Prosedur dan pelaksanan pemberian kredit pada BRI cabang Lamongan tidak boleh kurang dari
$80 \%$ dari prosedur yang ditetapkan oleh BRI cabang Lamongan, 2) Menganalisis faktor-faktor penyebab terjadinya kredit macet pada BRI Cabang Lamongan (Faktor internal, dan Faktor eksternal dari Bank), 3) Mengevaluasi penangan kredit macet pada BRI Cabang Lamongan (Rescheduling, Reconditioning, Retructaring, Kombinasi, dan Penyitaan Jaminan)

\section{HASIL PENELITIAN DAN PEMBAHASAN}

Prosedur pemberian kredit diawali dengan pengisian formulir pengajuan kredit oleh calon debitur serta melengkapi persyaratan yang tercantum didalamnya. Pelaksanakan pemberian kredit tersebut di atas pihak BRI telah mempunyai prosedur/ aturan baku yang harus dilaksanakan dan tidak dapat disimpangi, sebagaimana ditetapkan dalam Surat Keputusan Direksi PT. BRI (Persero) Tbk. NOKEP: S.26-DIR/ADK/06/2006 tentang Pedoman Pelaksanaan Kredit Bisnis Ritel PT. BRI (Persero) Tbk., hal ini mempunyai tujuan sebagai berikut: 1) Untuk melindungi dana masyarakat dan memelihara kepentingan dan kepercayaan masyarakat; 2) Untuk meminimalisir resiko yang dapat berpengaruh terhadap kesehatan dan kelangsungan usaha bank dengan melaksanakan prinsip kehatihatian dalam pemberian kredit dan asas-asas pemberian kredit yang sehat.

Kredit retail selain dari KRETAP dan KRESUN, untuk dapat menentukan apakah suatu pengajuan kredit dapat disetujui atau tidak, maka pihak BRI akan terlebih dahulu melakukan tahapan-tahapan sebagai berikut: 1) ADK kantor cabang bersama-sama dengan Pejabat Kredit Lini bidang RM (Relationship Management) bertanggung jawab untuk meneliti dan memastikan bahwa dokumen-dokumen kelengkapan paket kredit telah lengkap, masih berlaku, sah dan berkekuatan hukum. Pejabat Kredit Lini melakukan pemeriksaan lapangan, sedangkan ADK melakukan pemeriksaan administrasinya, 2) Hasil pemeriksaan paket kredit oleh ADK harus dituangkan dalam formulir pengawasan kelengkapan paket kredit disertai dengan opini ADK. Kemudian ADK mencatat 
tanggal penerusan paket kredit dalam Register Permohonan Kredit Kanca, 3) Paket kredit harus diusulkan dan disajikan secara tertulis, memuat beberapa atau semua hal berikut ini sesuai dengan keperluannya, 4) Khusus untuk hal yang berkaitan dengan perubahan suku bunga kredit provisi, biaya administrasi, dan tidak dipenuhinya negative convenants, persetujuan pejabat pemutus dapat dituangkan dalam form memorandum singkat yang berfungsi sebagai putusan, 5) Dalam melengkapi dokumen yang diperlukan Pejabat Pemrakarsa Kredit dapat melakukan konsultasi dengan, 6) ADK memantau penyampaian paket kredit sejak menerima dari Pejabat Pemrakarsa Kredit dan Pejabat Pemutus Kredit sampai rantai putusan diselesaikan.

Kredit macet yang terjadi pada BRI cabang Lamongan disebabkan adanya beberapa faktor. Faktor-faktor yang dapat menyebabkan terjadinya kredit bermasalah pada BRI cabang Lamongan antara lain: 1) Debitur menyalah gunakan kredit. Kredit yang disalurkan terlebih dahulu dilakukan perjanjian tujuan penggunan kredit yang akan diterima oleh debitur. Kredit macet yang terjadi di BRI Cabang Lamongan sebagian besar terjadi karena adanya penyalahgunaan kredit oleh debitur sebesar $74,23 \%$. Penyalahgunaan kredit ini disebabkan oleh kedit modal kerja tetapi digunakan untuk keperluan pribadi bukan untuk membiayai usaha, sehingga pada saat jatuh tempo debitur tidak dapat membayar kredit karena tidak ada sumber pendanaan lain, 2) Debitur mempunyai itikat kurang baik. Hasil penelitian yang dilakukan pada BRI Cabang Lamongan menunjukan bahwa sebagian kredit macet yang terjadi disebabkan oleh debitur yang dengan sengaja menunda pembayaran angsuran kredit dengan prosentase sebesar 3,69\%, 3) Debitur cedera janji. Bentuk pembayaran kredit ritel yang terdapat pada BRI Cabang Lamongan adalah dengan sistem kontrak, dimana angsuran tiap bulan yang dibayarkan oleh debitur hanya berupa bungan saja sedangkan utang pokok dibayarkan oleh debitur sesuai dengan kesepakatan yang telah dibuat. Kenyataannya debitur dalam pembayaran utang pokok pinjaman sering tidak tepat waktu dengan prosentase $19,92 \%$.

Faktor yang dapat menyebabkan terjadinya kredit macet yang berasal debitur dapat dilihat pada tabel 1:

Tabel 1. Faktor-faktor penyebab terjadinya kredit bermasalah Pada BRI cabang Lamongan

\begin{tabular}{lcc}
\hline Faktor-faktor penyebab terjadinya kredit bermasalah & 2010 & 2011 \\
\hline a. Debitur menyalah gunakan kredit & $65,09 \%$ & $74,23 \%$ \\
b. Debitur mempunyai itikat kurang baik & - & $3,69 \%$ \\
c. Debitur cedera janji & $28,30 \%$ & $19,92 \%$ \\
d. Lain-lain & $6,61 \%$ & $2,16 \%$ \\
\hline
\end{tabular}

Sumber: Laporan keuangan BRI cabang Lamongan

Pedoman pelaksanaan kredit pada BRI cabang Lamongan adalah sebagai berikut: 1) Penyelamatan kredit dilakukan melalui restrukturisasi yaitu upaya perbaikan yang dilakukan bank dalam kegiatan perkreditan terhadap debitur yang mengalami kesulitan untuk memenuhi kewajiban. 2) Penyelesaian kredit. Ada 3 model penyelesaian kredityang dilakukan oleh pihak BRI yaitu sebagai berikut: (a) Penyelesaian secara damai, Dilakukan terhadap debitur yang masih mempunyai itikad baik (kooperatif) untuk menyelesaikan kewajibannya. (b) Penyelesaian melalui saluran hukum atau melalui bantuan pihak ketiga. Penyelesaian kredit macet dengan bantuan Kejaksaan maupun dengan pengajuan klaim asuransi.

Hasil analisis menunjukkan bahwa kebijakan mengenai pemberian kredit pada BRI cabang Lamongan sudah baik karena telah sesuai dengan prosedur/aturan baku yang telah ditetapkan oleh PT. BRI (Persero) Tbk. Pusat. Sesuai dengan surat keputusan direksi PT. BRI (Persero) Tbk. NOKEP:S.26 -DIR/ADK/06/2006 tentang 
Pedoman Pelaksanaan Kredit Bisnis Ritel PT. BRI (Persero) Tbk. Bertujuan untuk melindungi dana masyarakat dan meminimalisir resiko yang dapat mempengaruhi kesehatan usaha bank dengan prinsip kehati-hatian dalam pemberian kredit.

Kurangnya pengawasan kredit yang dilakukan oleh pihak bank menyebabkan terjadinya penyalah gunaan kredit oleh nasabah, misalnya kredit modal kerja yang seharusnya digunakan untuk modal usaha tetapi digunakan oleh debitur untuk membeli kendaraan pribadi. Debitur mempunyai itikat kurang baik yaitu debitur dengan segaja membayar kredit tidak tepat waktu. Debitur melakukan cidera janji yang disebabkan debitur mengalami gagal usaha, sehingga menyebabkan debitur tidak dapat lagi membayar angsuran kredit tepat pada waktunya. Dari hasil analisis tentang faktor-faktor penyebab terjadinya kredit macet pada BRI cabang Lamongan terbesar dikarenakan penyalahgunaan kredit yang digunakan debitur dengan persentase sebesar $65,09 \%$.

Kredit ritail yang termasuk dalam kategori macet pada BRI cabang Lamongan pada tahun 2011 terdapat 11 kasus. Terdapat 3 kasus dilakukan penyelamatan kredit melalui 1 kali restrukturisasi berhasil. 6 kasus yang penyelesaiannya dilakukan melalui restrukturisasi yang sampai saat ini masih berjalan. Dari enam kasus tersebut, 2 kasus yang merupakan pelaksanaan restrukturisasi kali kedua, karena restrukturisasi yang pertama tidak dapat berhasil disebabkan karena cash flow perusahaan debitur yang bersangkutan terus menurun. 2 kasus kredit macet yang akan diselesaikan melalui parate eksekusi (PE) tetapi sebelum lelang dilaksanakan pihak debitur terlebih dahulu melunasi semua hutangnya dengan memperoleh keringanan pembayaran bunga dari pihak BRI Cabang Lamongan, salah satu telah dilaksanakan eksekusi.

\section{SIMPULAN}

Pelaksanaan pemberian kredit di PT. BRI (Persero) Tbk. Cabang Lamongan telah dilakukan sesuai prosedur yang telah ditentukan serta peraturan-peraturan pokok perkreditan yang berlaku.
Pihak BRI juga telah berusaha maksimal untuk meminimalisir terjadinya kredit bermasalah dengan mengadakan pembinaan dan pengawasan terhadap debitur dan manajemen perusahaannya, namun demikian masih terdapat penyimpangan. Faktor-faktor penyebab terjadinya kredit bermasalah di PT. BRI (Persero) Tbk. Cabang Lamongan adalah lebih karena faktor ekstern BRI yaitu karena sebab yang berasal dari pihak debitur. Untuk kredit ritel sebagian besar disebabkan oleh karena Debitur menyalah gunakan kredit, Debitur mempunyai itikat kurang baik, Debitur cedera janji.

Penyelesaian kredit bermasalah telah dilakukan pula oleh pihak BRI secara maksimal dan prosedural melalui tahapan-tahapan yang cukup panjang, sesuai dengan peraturan intern BRI yaitu Pedoman Pelaksanaan Kredit Bisnis Ritel PT. BRI (Persero) Tbk. dan SK Direksi Bank Indonesia Nomor No.27/162/DIR tanggal 31 Maret 1995 tentang Pedoman Penyusunan Kebijaksanaan Perkreditan Bank (PPKPB), namun demikian hasilnya belum maksimal pada beberapa pelaksanaan restrukturisasi sehingga dilakukan restrukturisasi kedua.

\section{DAFTAR PUSTAKA}

Gup, Benton E and Kolari, James W. 2005. Commercial Banking. John Wiley and Sons. USA.

Hasibuan, Malayu. 2001. Dasar-Dasar Perbankan, Cetakan Pertama. Bumi Aksara. Jakarta.

Kasmir. 2004. Bank dan Lembaga Keuangan Lainnya. PT Raja Grafindo Persada. Jakarta.

Kasmir. 2011. Dasar-Dasar Perbankan, Cetakan Ke- 9. PT. Raja Grafindo Persada. Jakarta.

Kuncoro, Mudrajat. 2002. Manjemen Perbankan, Edisi Pertama. BPFE. Yogyakarta.

Siti, Noorhayati Ekani. 2010. Prosedur Kredit Dan Upaya Mengatasi Kredit Bermasalah Pada PD. BPR BKK. Jati Kudus. 
Suyatno, Thomas, dkk. 2001. Kelembagaan

Perbankan, Edisi Tiga. PT. Gramedia Pustaka Utama. Jakarta.

Sumarni, Murti. 1993. Manajemen Pemasaran Bank, Edisi Revisi. Liberty. Yogyakarta.

Http://Www. Vibiznews.Com/News/ Banking_Insurance/2011/07/19/Jumlah-
Kredit-Macet Perbankan-Indonesia-HinggaMei-2011-Rp-34991-Triliun. Diakses Tanggal 28 November 2011 Jam 13.00 Taswan, Cand. 2010. Manajemen Perbankan Konsep Teknik Dan Aplikasi, Edisi dua. Upp Stim Ykpn Yogyakarta. Yogyakarta 